\title{
肝疾患の抗補体因子について
}

\author{
森 藤 隆 夫・渡 辺一雄 \\ 西間木友衛・吉田浩・粕川禮司
}

\author{
Anticomplementary activity of liver disease sera \\ Takao Morito, Kazuo Watanabe, \\ Tomoe Nishimagi, Hiroshi Yoshida and Reiji Kasukawa \\ IInd Department of Internal Medicine, Fukushima Medical College
}

【Summary】

\begin{abstract}
Anticomplementary activity (ACA) of five liver disease sera with no hemolytic complement activity and one IgG-myeloma serum was examined before and after heating at $56^{\circ} \mathrm{C}$ for $30 \mathrm{~min}$.

The ACA of IgG-myeloma serum was found only in the heated sample. However, the ACA of liver diseases sera was found in both unheated and heated samples.

Since ACA of liver disease sera was inhibited by rheumatoid arthritis serum but not by normal serum, IgG antibodies combined with some antigen or aggregated IgG were suspected as factors eliciting the ACA.

They might participate also in decreasing of hemolytic complement activity in the cold, which was frequently found in chronic liver disease sera.
\end{abstract}

Key words : hemolytic complement activity, anticomplementary activity, liver disease, rheumatoid factor

I.はじめに

抗補体活性 (Anticomplementary activity, 以下 $\mathrm{ACA})$ とは, $56^{\circ} \mathrm{C}, 30$ 分加熱非働化された血清が，モ ルモット補体 (guinea pig complement, 以下 GPC) を活性消費する現象である．この現象がみられる疾患と して, 骨䯣腫, SLE, 肝疾患, 梅瑇, その他の慢性炎症 疾患などが知られているが，ACA 因子としてその性状 が明らかにされたと思われるものは，骨髄腫血清中の加 熱変性した $\mathrm{M}$-蛋白 ${ }^{1)}$, SLE 血清中の DNA-抗 DNA 抗体結合物2などごく限られたものであり，それ以外の 疾患についての ACA 因子の性状はまだ明らかにされて いない.

福島県立医科大学第 2 内科
今回, 著者らは, 低補体価を示す肝疾患患者につき $56^{\circ} \mathrm{C}$ 加熱処理前の血清が示す $\mathrm{ACA}$ を測定し,さらに, $\mathrm{RA}$ 患者血清 (リウマチ因子) による $\mathrm{ACA}$ 抑制試験 を行い，本疾患の ACA 因子に補体結合性 IgG が関与 するか否かを検討した。

\section{II. 対象亡方法}

福島医大第 2 内科に入院し, 非働化血清の ACA が陽 性である慢性肝疾患患者で, 血清の溶血補体価が 2.0 $\mathrm{CH} 50$ 以下であった慢性肝炎 3 例, 肝硬変症 2 例を対象 とした. 同時に, 低補体価を示し, 肝生検で正常肝であ ることを確認した IgG 型骨髄腫例を比較対照として検 索に加えた. 上記患者血清は，型どおり早朝空腹時に採 血, 室温 2 時間放置後分離し, オみやかに以下の検索に 
表 1 ACA of unheated and heated sera

\begin{tabular}{|c|c|c|c|c|c|c|c|c|c|c|c|}
\hline & \multirow[b]{2}{*}{ patient } & \multirow[b]{2}{*}{ diagnosis } & \multirow[b]{2}{*}{ treatment } & \multirow[b]{2}{*}{1} & \multicolumn{6}{|c|}{ ACA. Dilution of serum, 1 to } & \multirow[b]{2}{*}{128} \\
\hline & & & & & 2 & 4 & 8 & 16 & 32 & 64 & \\
\hline \multirow[t]{2}{*}{1} & S.K. & $\mathrm{LC}^{1}$ & $A^{3}$ & -5 & - & - & - & - & \pm & + & + \\
\hline & & & $\mathrm{B}^{*}$ & - & - & - & - & \pm & + & + & + \\
\hline \multirow[t]{2}{*}{2} & S.A. & $\mathrm{LC}$ & A & - & - & - & - & - & \pm & + & + \\
\hline & & & $B$ & - & - & - & - & \pm & + & + & + \\
\hline \multirow[t]{2}{*}{3} & M.Y. & $\mathrm{CH}^{2}$ & $A$ & - & - & - & - & \pm & + & + & + \\
\hline & & & $B$ & - & - & - & - & \pm & + & + & + \\
\hline \multirow[t]{2}{*}{4} & Y.K. & $\mathrm{CH}$ & $A$ & - & - & - & - & \pm & + & + & + \\
\hline & & & $B$ & - & - & - & \pm & + & + & + & + \\
\hline \multirow[t]{2}{*}{5} & Y.K. & $\mathrm{CH}$ & A & - & - & - & \pm & + & + & + & + \\
\hline & & & $\mathrm{B}$ & - & - & \pm & + & + & + & + & + \\
\hline \multirow[t]{2}{*}{6} & M.T. & IgG-myelome & A & \pm & + & + & + & + & + & + & + \\
\hline & & & $\mathrm{B}$ & - & - & - & - & - & - & \pm & + \\
\hline
\end{tabular}

1 : Liver cirrhosis, 2 : Chronic hepatitis, $3:$ Unheated, $4:$ Heated,

$5:-$ (no hemolysis), \pm (partial hemolysis), + (complete hemolysis)

使用した.

\section{ACA の測定}

詳細は既報引で述べているので簡単に記す，倍々希釈 した被検血清の $50 \mu l$ と，あらかじめ $4.0 \mathrm{CH} 50 / \mathrm{m} l$ に 調整した GPC の $50 \mu l$ を microplate の各 well $に$ 入れよく混和し, $4^{\circ} \mathrm{C}$ overnight 反応させた. その後, 溶 血補体価測定に用いる感作血球 $50 \mu l$ を加えて $37^{\circ} \mathrm{C} 20$ 分反応させ, 溶血, 不溶血を判定した.そして約 $50 \%$ 不 溶血を示す血清の最終希釈倍数值を ACA 力価とした.

\section{RA 血清による ACA 抑制試験}

Milgrom ${ }^{4}$ ，Kasukawa ${ }^{5)}$ の方法に準して行った。 ず ACA 測定と同様に microplate 上で被検血清の倍々 希釈系列を 2 列っくり，一方の希釈系列に非働化した健 常人 $A B$ 型血清 $(N)$, 他方に非働化 RA 患者血清 (LFT 1,280 倍, $\mathrm{ACA}$ 陰性) のおのおの 5 倍希釈液 $50 \mu l$ を 混和し，室温で 3 時間反応させた．その後 GPC を加え $4^{\circ} \mathrm{C}$ overnight 放置し, 感作血球を加えて $37^{\circ} \mathrm{C} 20$ 分 反応させ溶血，不溶血を判定した，そして RA 血清添 加系列の ACA が, 健常人血清添加系列の ACA より 3 管以上減弱している場合を ACA 抑制試験陽性とし た.

\section{III. 成 樍}

\section{1. 肝疾患之骨鼍腫血清の ACA (表 1)}

同一肝疾患症例について未処理血清と非㗢 化血清の ACA を測定すると，表 1，S.K. 例のごとく，末処理血 清で 32 倍希彩まで，非働化血清で 16 倍希釈までと非加 熱と加熱の両血清に ACA が認められた. 他の4例の 肝疾患においても未処理血清で 32 8 倍, 非働化例で 16〜4 倍の ACA が認められた. 一方, IgG 型骨髄腫 (M.T.) 例に招いては未処理血清の ACA はまったく認 められなかったが，非働化血清では 64 倍まで ACA が 認められた。

\section{RA 血清による ACA 抑制試験（表 2）}

肝疾患群では，未処理血清と非働化血清の両者に ACA が認められたことから両血清につき検討した. 先の S.K. 例について具体的に示すと，末処理血清では健常人血清 (N) 添加で 32 倍希釈までみられた ACA 力価が， RA 血清 (RA) 添加により不溶血は 2 倍希釈までに減弱し， 4 管の ACA 抑制がみられ，非働化血清でも 3 管の抑制 がみられた. 骨髄腫の非働化血清では, 健常人血清添加 では64 倍までみられた ACA が, RA 血清添加でほぼ 完全に抑制された. 室温で分離された血清検体で溶血活 性のみられない他の 4 例についても同様の検討を行い， 
表 2 Inhibition test of ACA by RA serum

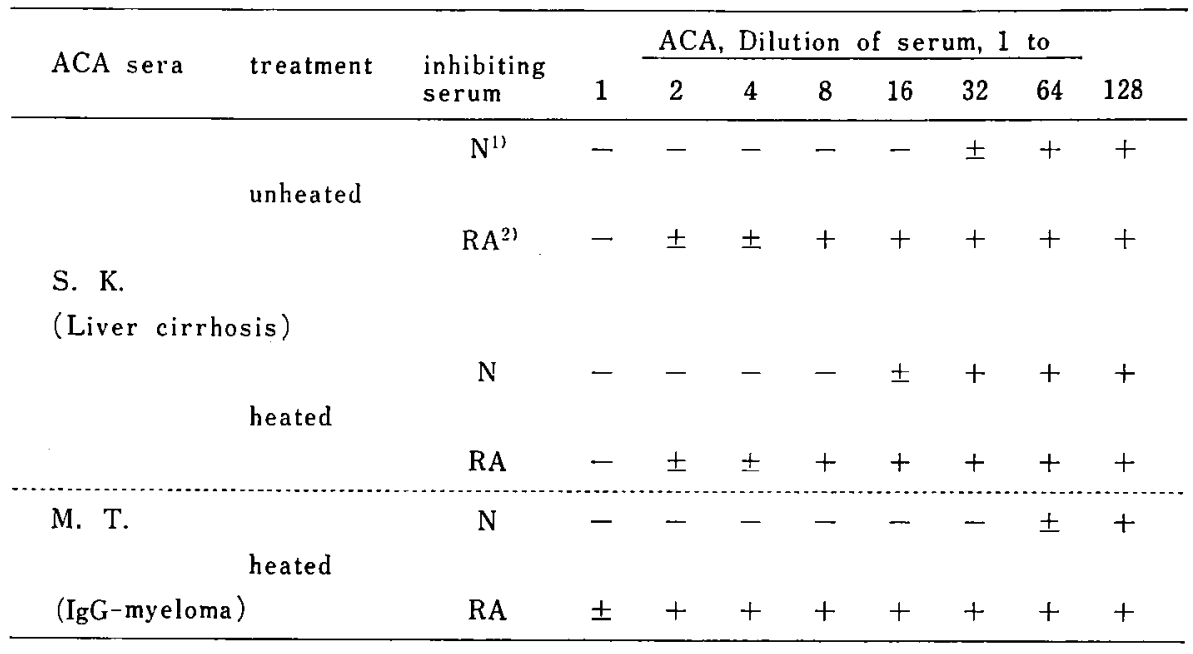

1 : Normal serum, $2:$ Rheumatoid arthritis serum

表 3 Complement activity and ACA of liver disease sera inhibited by normal or rheumatoid sera

\begin{tabular}{lccccc}
\hline \multirow{2}{*}{$\begin{array}{l}\text { Sera } \\
\text { (disease) }\end{array}$} & \multicolumn{2}{c}{ CH50 } & & \multicolumn{2}{c}{$\begin{array}{c}\text { ACA, titer of unheated sera } \\
\text { inhibited by serum of }\end{array}$} \\
\cline { 2 - 4 } \cline { 5 - 6 } \cline { 5 - 6 } Y. K. (CH) & $<2.0$ & 28.0 & & $\times 8$ & RA \\
M. Y. (CH) & $<2.0$ & 32.0 & & $\times 16$ & 0 \\
S. K. (LC) & $<2.0$ & 16.0 & & $\times 32$ & $\times 2$ \\
Y. K. (CH) & $<2.0$ & $<2.0$ & & $\times 16$ & $\times 4$ \\
S. A. (LC) & $<2.0$ & $<2.0$ & & $\times 32$ & $\times 1$ \\
\hline
\end{tabular}

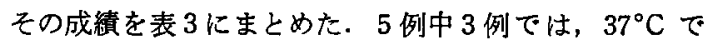
血清分離を行うと, いずれも $15 \mathrm{CH} 50$ 以上の溶血活性 が認められたが，他の 2 例では，室温分離例と同様に著 明な溶血活性の低下が認められた。 室温分離検体 例で は，いずれも ACA が認められ，それは，S.K. 例同様, いずれも RA 血清加により抑制された，以上のことか ら ACA をひきおこす因子は，補体結合性 IgG であろ うと考えられた。

\section{IV. 若案}

肝疾患患者血清中にみられる ACA 因子として， immune complex (IC), cryoglobulin (Cryo), 変性 r-globulin (aggr-gl) などが推定されている.ICについ ては, 肝炎ウイルスに関連した種々の抗原, 抗体系が知 られるようになり，それにつれて，劇症肝炎や一部の急 性・慢性肝炎，または，腎炎や関節炎などの，いわゆる， extra-hepatic syndrome の原因として IC が考えられ るようになった ${ }^{6,7)}$. Cryo については，著者らは前報
にて，慢性肝疾患の低補体価例に Cryo 陽性例が多いこ と, Cryo 抽出後血清の ACA が抽出前血清の ACA よ り低下していること，その Cryo は，ICに類似した生 物学的活性を有することなどを報告した，一方，aggrglについては, 慢性肝疾患では, 高 $\gamma$-globulin 血症や 異常荊質反応が多くみられること，さらに，これらの血 清が ACA 測定に際し非働化されることなどから，骨㵦 腫と同様, $\gamma$-globulin が in vitro で変性重合した結果, ACA が出現するものと推定されている8).

従来, ACA を測定する場合に血清を非働化している が，その理由は，被検血清自身の溶血活性を消費させな ければ，指標とする補体（GPC）の活性を判定すること ができないためと考えられる，しかし，分離直後から溶 血活性を示さない血清なら，加熱処理を要せずに ACA

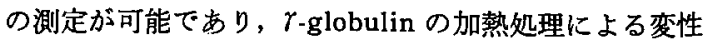
の可能性も無視できよう：このような理由から，今回， 肝疾患の低補体価末処理血清につき, ACA を検討した。 リウマチ因子は，抗原と結合した IgG 抗体や，加熱 
その他の処理で変性した IgG 分子の Fc 部分と結合す る抗体で，通常の方法で検出されるのは IgM に属する. リウマチ因子とこれら IgG がまえもって結合すると， IgG と補体との結合性は抑制されることが知られてお $\eta^{11)}$ ，この性質を利用して，血清中の補体結合因子が IgG か否かを検索できる (RA による ACA 抑制試験). 寸 なわち，被検血清とリウマチ患者血清 (RA) をあらか じめ反応させてから ACA を測定すると，ACA 因子が IgG である場合には, RF が IgG の Fc 部分に結合す ることによって後から加えられた補体の結合が抑制され て, 補体が残存するため, 感作血球の溶血の促進一ACA の抑制一がみられる. Kasukawa ${ }^{1)}$ は, IgG 型骨䯣腫血 清の ACA が RA 血清で抑制されること，本血清と RA 血清を寒天内で反応させると沈降線が生し，この沈降線 は $63^{\circ} \mathrm{C}$ 加熱変性したヒト Fraction II と融合すること を認め，骨髄腫血清中の ACA 因子は，加熱で変性し た IgG 分子であることを明らかにしている.

今回, 著者らは, 溶血活性をもたない慢性肝疾患の未 処理血清と非䣦化血清の ACA を測定し，さらに，RA 血清による ACA 抑制試験を行った結果，1．低補体価 を呈する肝疾患では，未処理血清でも ACA が認めら れること，2，骨髄腫血清では従来いわれているごとく， 加熱非衔化されてからはじめて ACA が出現すること， 3. 両疾患の ACA は RA 血清で抑制されること,など の成績を得た。

慢性肝疾患では polyclonal gammopathy，異常膠質 反応, 自己抗体, 異種抗体などが認められ，これら不安 定な血清蛋白が血清分離後の凍結, 融解, 加熱などの処 理でなんらかの影響を受けることは十分予想されよう。 しかし，今回の検索に用いた肝疾患血清は分離直後の血 清であり，加熱処理も加えられていない，それにもかか わらず ACA が認められ，それは RA 血清で抑制され たことは, 肝疾患では血清分離直後から，たんに変性重 合した IgG 分子であれ，抗原と結合した IgG 抗体で あれ, 補体結合性 IgG 分子が存在していることを示す ものと考えられた. しかし，これら慢性肝疾患が，流血 中においても補体結合性 IgGにより低補体価の状態に あるのではないことは, 血漿や $37^{\circ} \mathrm{C}$ 分離血清が正常域 に近い溶血活性を示すことから明らかであり，採取され た血液が in vitro で㠜固する閒に，IgG 分子になんら かの変化が生じ, 補体結合性を得るようになったと考え るべきであろう．以前に著者 ${ }^{9}$ らは，室温で分離した血 清の補体価が低下しているにもかかわらず，血漿の補体
価が正常域にある症例でも，採血後血清を $37^{\circ} \mathrm{C}$ で分離 した場合には，補体価の低下がみられないことを報告し た.この現象の解釈として低温での補体結合性をもつ IgG 抗体かそれに類似した物犋があるために，in vitro で補体が活性消費された結果, 低補体価になると解积し た. そして, 通常の室温でも $4^{\circ} \mathrm{C}$ 前後の低温に比べれ ば，程度は軽いが同様の機序で分離血清が低補体価を示 すと推定された．このような考えから，肝疾患における 被検血清と GPC の反応における温度条件を変えた場合 の ACA を観察し，メルカプトエタノール処理前後の ACA の変化, cryo の性状, IC の有無などの成績10,11) を発表してきたが，低補体価群と正常補体価群との間 に，いずれも明確な差異は見い出せなかった。

今回対象とした低補体価を示した慢性肝疾患例では, 全例において, 未処理血清に ACA が認められ, その ACA は, IgG 型骨髄腫と同様, RA 血清により抑制さ れる性質のものであった.これらの成績は, 肝疾患の ACA 因子が補体結合性 IgG であることを示唆するも のである.また, この 5 例中 3 例では, 室温分離血清が 低補体価を示すものの, $37^{\circ} \mathrm{C}$ で分離した場合には, 明 らかな溶血活性が認められ, IgG 分子が $37^{\circ} \mathrm{C}$ より $4^{\circ} \mathrm{C}$ で $\mathrm{Cl}$ を結合しやすいこと ${ }^{12)}$ 考慮するなら，低温下で 溶血補体価が減弱する現象にもこの補体結合性 IgG が， 強く関与することが推察される.

一方, $37^{\circ} \mathrm{C}$ 分離血清でも溶血活性がみられない症例 については, 上記 IgG 分子がより不安定であるため, 流血中から in vitro に採り出されることのみで変性重 合する可能性も推定されたが，血獎でも同様の低下がみ られることから，骨髄腫例（8）同様，生体内ですでに

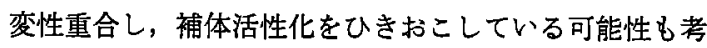
えられた.さらに, immune complex による活性化な どの免疫学的機序の他に，IgG 以外の ACA 因子の関 与, 補体成分産生の低下などを考虑しての検索が必要で あろうと思われた。

\section{V. まとめ}

低補体価を示す慢性肝疾患について，加熱処理前後血 清の抗補体活性 (ACA) を測定し，さらに，RA 血清 による ACA 抑制試験を行い，以下の成續を得た。

1. 肝疾患では, 未処理と非働化の両血清に ACA が 認められた。

2.この ACA が RA 血清により抑制されたことか ら，本因子は，補体結合性 IgG 分子と思われた。 
文献

1) Kasukawa, R., Yoshida, T. and Milgrom, F.: Inhibition of complement mediated hemolysis by rheumatoid arthritis sera studied in agarose gel. Int. Arch. Allergy, $38:$ 168 174, 1970.

2）天野哲基：全身性エリテマトーデスの抗補体作用 に関する研究, 第 2 編基礎的考察. 岡山医誌, 90 : 527 535, 1978.

3）森藤隆夫・鈴木秀幸・西閒木友衛 - 佐藤幹夫 · 大

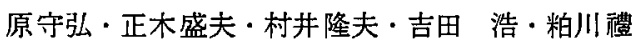
司・吉田越夫 : 肝疾患の抗補体活性に関する研究. 肝臟, $19: 362 \sim 370,1978$.

4) Milgrom, F. \& Schultz, R.T. : Serodiagnosis of rheumatoid arthritis based on inhibition of anticomplementariness of denatured Fraction II. Int. Arch. Allergy, $27: 338 \sim 345,1965$.

5) Kasukawa, R., Yoshida, H., Yoshida, T. \& Milgrom, F. : Reaction of G-myeloma sera with rheumatoid arthritis sera. Int. Arch. Allergy, $38: 590 \sim 597,1970$.

6) Shulman, N.R. \& Barker, L.F. : Virus-like antigen, antibody and antigen-antibody comp- lexes in hepatitis measured by complement fixation. Science, $165: 304 \sim 306,1969$.

7) Alpert, E., Isselbacher, K.J. and Schur, P.H. : The pathogenesis of arthritis associated with viral hepatitis. New Eng. J. Med., 285 : 185 $189,1971$.

8）吉田 浩・森藤隆夫・尾田貞彦・粕川禮司 - 吉田 赴夫 : 各種疾患患者血清における抗補体活性. 臨 床免疫, $8: 311 \sim 320,1976$.

9）西間木友衛・森藤隆夫・吉田 浩・粕川禮司・吉 田起夫 : 寒天内溶血反忘による補体の研究. 臨床 免疫, $8: 939 \sim 943,1976$.

10）森藤隆夫・吉田 浩・粕川禮司・吉田赴夫：抗補 体に関する研究. 蹦床免疫, 8 : 945 950, 1976.

11）森藤隆夫・佐藤幹夫・鈴木秀幸・吉田 浩・粕川 禮司・吉田赴夫：肝疾患患者血清中の immune complex について. 肝臟, $20: 559 \sim 565,1979$.

12) Tamura, N. \& Nelson, N.R. : The purification and reactivity of the first component of com. plement from guinea pig, human and canine sera. J. Immunology, $101: 1333 \sim 1345,1968$. 